\title{
Editorial
}

\section{Organic Rankine Cycle for Energy Recovery System}

\author{
Andrea De Pascale $\mathbb{D}$
}

Citation: De Pascale, A. Organic Rankine Cycle for Energy Recovery System. Energies 2021, 14, 5253. https://doi.org/10.3390/en14175253

Received: 20 July 2021

Accepted: 11 August 2021

Published: 25 August 2021

Publisher's Note: MDPI stays neutral with regard to jurisdictional claims in published maps and institutional affiliations.

Copyright: (C) 2021 by the author. Licensee MDPI, Basel, Switzerland. This article is an open access article distributed under the terms and conditions of the Creative Commons Attribution (CC BY) license (https:// creativecommons.org/licenses/by/ $4.0 /)$.
Alma Mater Studiorum, Università di Bologna, DIN, Viale del Risorgimento 2, 40136 Bologna, Italy; andrea.depascale@unibo.it; Tel.: +39-051-209-3310

\section{Introduction}

This book contains the successful invited submissions [1-9] to a Special Issue of Energies entitled "Organic Rankine Cycle for Energy Recovery System", focusing on a modern technology committed to energy saving and thus capable of producing positive environmental outcomes. Indeed, the organic Rankine cycle (ORC) is a thermodynamic concept already demonstrated as an engineering viable solution for waste heat recovery systems. Industrial realizations of the ORC in large- to small-scale applications are currently available, with power sizes ranging from few tens of $\mathrm{kW}$ to several $\mathrm{MW}$ of electric power output. In the near future, this technology can play an increasing role within the energy generation sectors and can help achieve the carbon footprint reduction targets of many industrial processes. As also demonstrated within this book, there are still many un-used hot streams available for recovery in various stationary power generators for civil and tertiary applications and in several highly intensive industries. Additional applications can come from the transportation sector, where waste engine heat in heavy vehicles and ships can be used to achieve fuel savings. Moreover, low-enthalpy flows from renewable sources can be exploited in thermodynamic cycles based on the Rankine architecture.

The original call for publication within the book included the following topics of interest:

- Waste-heat recovery (WHR) applications

- Advanced thermodynamic cycles

- Combined heat and power (CHP) generation

- Expanders for waste-heat recovery

- $\quad$ Renewable heat and low-enthalpy applications

- $\quad$ Experiments on micro-ORC generators

- New organic fluids for power generation

- $\quad$ New integrations of ORC with other energy systems

\section{Papers Included in the Special Issue}

In this general framework, this Special Issue focuses on selected research and application cases of the ORC-based waste-heat recovery solution. The current state of the art of the ORC technology is considered as a foundation and some cutting-edge research activities ongoing are examined by the authors participating in the issue. In particular, papers included in this publication cover the following aspects:

- the study by Andreasen et al. [1] refers to the research field of working fluid selection, as part of the ORC optimal design; a comparative modelling analysis is carried out, using different methods for the ORC thermodynamic design performance assessment; both pure fluids and zeotropic mixture working fluids are considered, in order to show the effect of the fluid glide characteristics on performance.

- $\quad$ The papers by Valencia et al. [2] present a numerical study on energy and exergy performance of ORC as bottomer of a reciprocating gas engine, while the study by Carcasci et al. [3] analyses ORC off-design performance as WHR of gas turbines. These two studies consider different ORC configurations and fluids and both papers show 
the actual applicability of the technology to well established stationary prime movers for the 1-10 MW size range of power.

- Branchini et al. [4] analyse, in their paper, the ORC design and off-design performance in a WHR combined heat and power annual production scenario; the study offers a thermodynamic and economic parametric comparison of different most common fluids and layout options; the study also shows that the ORC application to existing CHP energy systems can be implemented, obtaining improved energy savings.

- Baldasso et al. [5] consider the potential of ORC on board of ships; a simplified method based on a set of precalculated regression curves of ORC performance is introduced to assess the techno-economic feasibility of the waste heat recovery applied to the engine of the ship.

- A representative example of an ORC plant integrated with a biomass boiler is provided by Stoppato et al. [6], where the main focus is on the LCA technique application and the calculation of carbon footprint.

- A study on a possible ORC integration with a supercritical $\mathrm{CO}_{2}$ gas turbine-based cycle is performed by Espinel-Blanco et al. [7]; the study quantifies the capability of ORC to recover residual heat in complex and advanced energy systems, provided a proper matching of temperature levels.

- Fadiga et al. [8] perform a numerical analysis based on dynamic mashing technique of a volumetric expander of scroll type design for ORC application.

- Casari et al. [9] numerically investigate specific fluid dynamic issues, related with pressure oscillations and flow cavitation, which may occur in a pump of a micro-ORC system operated with organic fluids.

\section{Conclusions}

The research papers included in this Special Issue of Energies offer some insight into the ongoing scientific explorations in the field of organic Rankine cycles. As reflected by the content of this Special Issue, the applicability of ORC to many heat discharging process is feasible with encouraging performance. A well-established output of the studies on organic Rankine cycles is the existing potential to still harvest energy from plenty of residual low-quality heat flows. Nevertheless, some critical issues are still unresolved or require further research efforts. For example, the main points of interest are: (i) cycle arrangement, (ii) thermodynamic design, (iii) components size and geometry, and (iv) operating fluids; all these aspects should be properly optimized for each application. Topics not covered in this book-which is focused on stationary energy systems-are related to mobile applications of ORC, i.e., the same technology has been proposed to be coupled with fuel-based engines on board trucks. A lot of research effort is also being made in this field, while feasibility is still to be validated within industry. The dynamic modelling of ORC when fed with variable heat sources is also an important aspect; finally, the environmental-techno-economic feasibility is a critical point.

Funding: This research received no external funding.

Acknowledgments: The Special Issue guest editor would like to thank all the authors and the reviewers for the high quality of the submissions. Moreover, the editor is grateful to MDPI for the invitation to act as guest editor of this Special Issue and he is indebted to the editorial staff of the journal Energies for their kind administrative support, co-operation and patience.

Conflicts of Interest: The author declares no conflict of interest.

\section{References}

1. Andreasen, J.G.; Kærn, M.R.; Haglind, F. Assessment of methods for performance comparison of pure and zeotropic working fluids for organic rankine cycle power systems. Energies 2019, 12, 1783. [CrossRef]

2. Valencia, G.; Fontalvo, A.; Cárdenas, Y.; Duarte, J.; Isaza, C. Energy and exergy analysis of different exhaust waste heat recovery systems for natural gas engine based on ORC. Energies 2019, 12, 2378. [CrossRef] 
3. Carcasci, C.; Cheli, L.; Lubello, P.; Winchler, L. Off-design performances of an organic rankine cycle for waste heat recovery from gas turbines. Energies 2020, 13, 1105. [CrossRef]

4. Branchini, L.; De Pascale, A.; Melino, F.; Torricelli, N. Optimum organic rankine cycle design for the application in a CHP unit feeding a district heating network. Energies 2020, 13, 1314. [CrossRef]

5. Baldasso, E.; Mondejar, M.E.; Larsen, U.; Haglind, F. Regression models for the evaluation of the techno-economic potential of organic rankine cycle-based waste heat recovery systems on board ships using low sulfur fuels. Energies 2020, 13, 1378. [CrossRef]

6. Stoppato, A.; Benato, A. Life cycle assessment of a commercially available organic rankine cycle unit coupled with a biomass boiler. Energies 2020, 13, 1835. [CrossRef]

7. Espinel Blanco, E.; Valencia Ochoa, G.; Duarte Forero, J. Thermodynamic, exergy and environmental impact assessment of S-CO2 brayton cycle coupled with ORC as bottoming cycle. Energies 2020, 13, 2259. [CrossRef]

8. Fadiga, E.; Casari, N.; Suman, A.; Pinelli, M. Structured mesh generation and numerical analysis of a scroll expander in an open-source environment. Energies 2020, 13, 666. [CrossRef]

9. Casari, N.; Fadiga, E.; Pinelli, M.; Randi, S.; Suman, A. Pressure pulsation and cavitation phenomena in a micro-ORC system. Energies 2019, 12, 2186. [CrossRef] 